\title{
Digital public sphere and Palestine-Israel conflict: A conceptual analysis of news coverage
}

\author{
Musharaf Zahoor*1 $^{\text {| Najma Sadiq }}{ }^{2}$
}

1. Centre for International Peace and Stability, National University of Sciences and Technology (NUST), Islamabad, Pakistan.

2. School of Social Sciences and Humanities (S3H), National University of Sciences and Technology (NUST), Islamabad, Pakistan.

Correspondence Emails: zahoor167pcips@nipcons.nust.edu.pk|musharafzahoor2001@yahoo.com

\begin{abstract}
The news coverage of conflicts has transformed with the introduction of digital media and social media platforms. The available literature on media coverage of Palestine-Israel conflict is mainly focused on traditional news coverage or social media dimension of the conflict information. There exists a literature gap on social media coverage of Palestine-Israel conflict by the traditional news organizations. This study explores the changing pattern of traditional media's coverage of the longstanding conflict in the wake of new communication technologies through appraisal of the existing literature. The analysis revealed that the traditional news organizations have adopted social networking platforms as a business model to cover the Palestine-Israel conflict. It was found that the traditional news outlets use the new media because it is cost-effective and have instantaneous outreach to maximum number of netizens. The new tools of communication offer multimedia platforms where conflict-related text, videos and images can be posted simultaneously. The study proposes to conduct future research on mediaconflict relationship by focusing the use of new communication tools by the traditional media.
\end{abstract}

Article History

Received:

January 3, 2021

Last Revised:

May 12, 2021

Accepted:

May 17, 2021

Published:

May 22, 2021

Keywords: Israel-Palestine conflict, conflict reporting, social media, traditional news media, digitalisation of conflict, media and conflicts, news business.

How to Cite: Zahoor, M. \& Sadiq, N. (2021). Digital public sphere and Palestine-Israel conflict: A conceptual analysis of news coverage. Liberal Arts and Social Sciences International Journal (LASSIJ), 5(1), 168-181. https://doi.org/10.47264/idea.lassij/5.1.12

Publisher's Note: IDEA PUBLISHERS (IDEA Journals Group) stands neutral with regard to the jurisdictional claims in the published maps and the institutional affiliations.

Copyright: () 2021 The Author(s), published by IDEA PUBLISHERS (IDEA Journals Group). This is an Open Access article published under the Creative Commons Attribution-NonCommercial 4.0 International License (http://creativecommons.org/licenses/by-nc/4.0/) 


\section{Introduction}

The advent of new communication technologies has revolutionized the conflict coverage. The instantaneous vast outreach through social networking platforms draws a lot of public attention to the conflict-related news. This kind of communication also impact policy decisions related to conflict in view of information and public opinion. A substantial body of available literature about coverage of Palestine-Israel conflict has either focused on the traditional communication sources such as television, radio and newspapers or social media platforms including Facebook, Twitter and others (Wolfsfeld et al., 2008; Deprez \& Raeymaeckers, 2010; Baden \& Tenenboim-Weinblatt, 2017; Arqoub \& Ozad, 2019; Friedman \& Herfroy-Mischler, 2020; Kirk, 2020; Shomron \& Schejter, 2020; Segev \& Blondheim, 2013; Kuntsman \& Stein, 2015; Groves, 2017; Pennington, 2020).

This research has identified gap in the existing literature about use of social media platforms by the traditional news organizations to cover the Palestine-Israel conflict. This kind of a study is important as the traditional news outlets such as TV, newspapers and even radio stations have adopted the social networking platforms as part of their news gathering and distribution mechanism. The previous studies about relationship of media and Palestine-Israel conflict mostly focused traditional news organizations. The growing relationship of the old and new media with respect to the coverage of the longstanding conflict has not been the focus of the previous studies. The advent of social networking platforms such as Facebook and Twitter have revolutionized the communication worldwide (Cox, 2016, p. 221). The information can reach out to unlimited audiences within no time. The era of one-way communication has ended. Bottom-up participatory communication and multiplicity of information sources are the hallmarks of the new media. The conflict parties, journalists, humanitarian organizations, and warring groups all are present on social networking websites. The audience can become part of the news production process and also post their opinion instantly (Ferrer-Conill \& Tandoc, 2018, p. 2).

The social networking platforms are accessible worldwide. These platforms offer multimedia communication devoid of structural barriers such as landing rights and distribution networks. They can instantaneously distribute the conflict related information to large number of audiences at the same time. They have also eased the information gathering from conflict zones. In recent Syrian conflict, the images sent out by the activists and warring parties were the only source for the outside world and by this way they kept the conflict alive in the mainstream media (Pantti, 2013, p. 1). This study has explored that the new communication tools not only save resources of the traditional news organizations in the coverage of PalestineIsrael conflict but also promote their brand and help them to dominate the conflict-related discourse in the digital sphere. Viewing the merits of social networking platforms, the traditional journalists and organization have adopted these forums as part of their business models (Hong, 2012, p. 70).

In the backdrop of changing communication technologies, this study suggests that the media impact on the conflict dynamics needs to be re-examined. This study also identified that new communication sources have not only complicated the flow of conflict-related information but also its resolution. The research is based on appraisal of the existing literature and highlights the business and professional logic behind the social media coverage of Palestine-Israel conflict by the traditional news organizations. The research also underscores that the traditional media has become more relevant due to professional reputation and credibility. 


\subsection{Social media as a business model}

The versatility and interactivity of the internet distinguishes it from other media. It can deliver text, graphics, images, audio, and video at the same time, and thus can provide the functions of other mass media (Carveth, 2004, p. 265). All international media organizations have their twitter handles, Facebook pages and YouTube channels. The examination of outbound hyperlinking of top 25 US national newspapers from 2012 onward revealed that 98 percent of newspapers' websites contained outbound links to Twitter and Facebook that reflects the increasing role of social networking websites in news media (Weber, 2017, p. 84). The newspapers have now transferred from paper to virtual screen where they can post their stories with more ease and even update a news story round the clock.

For traditional news media, the social networking platforms are a source to reach out to the maximum number of audiences. The news channels invite the audience to provide input for news production and story writing through social networking websites (Duffy, 2011, pp. 3-4). Many scholars believe that the traditional news organizations' use of social media for news distribution is not really an integration. Heo and Park (2014) in their study about use of Youtube by Korean newspapers for production and bradcasting news contended that the interaction of traditional and social media is aimed to diversify the distribution and consumption of the news and not the integration of both (Heo \& Park, 2014, p. 2901). Momberg (2009) and Reece (2009) believe that the main advantage of integrating social media into an online news service is brand and community building (Stassen, 2010, p. 123). The traidtional news organizations have also transformed themselves according to the needs of new technologies. The newspapers have become e-newspaper, TV channels have transformed into web tv. A person holding a mobile device can read newspapers and watch television on a single digital platform.

\subsection{Brand promotion through social media}

The social media networks have become a platform for public engagement and public information allowing companies to integrate their business strategies into Social Networking Software (SNS) to derive value from areas such as customer traffic, customer loyalty, brand awareness and reputation (Sivarajah et al., 2019, p. 4). In the news business, time to deliver the news counts too much to avoid being out scooped by the competitors. The social networking websites are easy to access on computer and smart phones and facilitate the communication between companies and customers and increases the communication between customers about companies (Alboqami et al., 2015, p. 339). The use of social media also provides a rich knowledge to the news organizations about the preferences of the consumers about the news they like to consume which is defined as Electronic Word of Mouth (eWOM). Word of mouth (WOM) refers to communications among consumers about products and services of brands (p. 342).

The international language news organizations have their followers in millions around the globe. A post or a Tweet on social media reaches out to millions of people within few seconds. The responses by the audience in terms of shares, Retweets and comments further boost the brand name as many latent links are created which gradually mature and become part of the community. There are two approaches of use of social media as a business model, (1) social media adoption approach, and (2) social media content strategy (Araujo \& Neijens, 2012; Brennan \& Croft 2012; Swani et al., 2014). Businesses simultaneously adopt multiple social 
media tools for the purpose of brand building (Tafesse, 2015, p. 929). The use of logos as profile picture distinguishes the organization. The news organizations also utilize various optimization techniques.

\subsection{Fake news challenge on social media and role of traditional media}

The information bombardment on digital platforms has complicated the consumption of relevant and authentic information. The fake news issue mars the image of social media. Talwar et al. (2020) are of the view that the anonymity user-generate content and geographical distance may further encourage the sharing of fake news (Talwar et al., 2020, p. 1). Fake news are spread with certain motives and harm organizations, governments and also mislead people's perception about certain issues (Ozbay \& Alatas, 2019, p. 3). There are even fake websites, which resemble to legitimate news organizations to spread fake content and disinformation for political or financial gains (Zhang \& Ghorbani, 2020, p. 2). The foreign manipulation of social media platforms poses another threat. The bot accounts are manipulating political processes in the countries as it happened in 2016 U.S. Presidential elections (Gorwa \& Guilbeault, 2020, p. 227).

In conflict situation, the opponent parties try to generate discourse that may support their position by undermining the democratic and inclusive characteristics of these platforms. The traditional news organizations can unmask these manipulation attempts. The issue of fake news has even moved the technology experts to find out solutions for to scuttle this trend. The inventor of the World Wide Web, Sir Tim Berners-Lee, unveiled a five-year plan to tackle data abuse and fake news in an open letter to mark the web's 28th anniversary (BBC, 2017). Similarly, after London attacks on 3 April 2017, Al-Jazeera posted on its Twitter handle a comment 'Don't believe these fake stories about London attacks'. The Tweet warned the people not to believe everything online after an attack (Al-Jazeera, 2017). In the traditional media, the reporters and editors professionally screen the details of each information and publish a story contrary to the social media where anyone can post a video clip and a piece of information without considering journalistic ethics.

\subsection{Why audience use social media?}

Boyd and Ellison (2007) contend that the social networking sites are not only providing space to meet strangers but they also enable users to articulate and make visible their social networks that results in connections between individuals that would not otherwise be made (Boyd \& Ellison, 2008, p. 211). These meetings are not the objective of these interactions, but they frequently occur between latent ties (Boyd \& Ellison, 2008 ). Miller et al. (2016) argued that the social media is scalable sociality as one scale is from the most private to the most public and the second scale is from the smallest group to the largest groups (Mille et al. 2016). The social media is vibrant, dynamic and flexible platform of communication. This communication not only involves textual or visual communication but live interaction as well. It caters the needs of the people from different cultural backgrounds at a time with different requirements. Unlike traditional media, people can see, watch and respond at a time anywhere in the world on these social networking websites.

The social media provides a space to the people where they can easily access maximum sources of information which was not possible through traditional media. They can become part of the story by expressing their own point of view which is visible to millions around the globe. 
People are attention seekers by nature therefore it happens sometimes that their comments get more likes or retweets than the actual story. A study on social media sharing through application of gratification theory found out that the primary gratifications for social media users are status seeking, socializing, and receiving information (Bullard, 2015). The participatory nature of the social media is often termed as politics 2.0 which refers to the use of internet's lowered transaction costs and information abundance for building more participatory and interactive political institutions (Stieglitz \& Dang-Xuan, 2012, p. 1285).

\section{Theoretical and Methodological Approach}

The present theoretical appraisal probes the evolving academic debate around the relationship of media and Palestine-Israel conflict after the advent of social networking platforms. This study reviewed the most recent literature on relationship of media and Palestine-Israel conflict that helped to identify the gap in the existing literature. It was found that there are limited. This study has used 'arrested conflict' approach that deals with the third phase of mediatization explained by Zhang (2019). This approach highlights the traditional/professional media's use of social media for the conflict coverage. This study also highlighted the causes of traditional news organizations' use of social media to cover Palestine-Israel conflict. The analysis facilitated to form the suggestion to redirect academic debate towards growing social media coverage of the conflict by traditional news organizations. It also helped to suggest that future media impact studies must be based on social media coverage of the conflicts by the traditional news organizations.

\section{History of media coverage of Palestine-Israel conflict}

The news about conflict, wars and violence gets immediate media attention. Wolfsfeld (2004) argued that the conflict stories win awards for journalists therefore, they aspire to be war correspondents and consider it their greatest accomplishment (Wolfsfeld, 2004, p. 15). The Palestine-Israel conflict is one of the oldest conflicts of the contemporary history. Since the beginning, the conflict has drawn extensive international media attention.

The number of Europeans visitors to the Holy land increased manifolds from 1831 to 1840 and large number of books were published after 1840 about Palestine, narrating stories resembled to the biblical history (Moscrop, 2000, pp. 19-23). This was the initial exposure of the world to the land of Palestine in the modern history. In Palestine, the first Hebrew language newspaper Ha-Levanon was published in 1862 (Suleiman, 2009, p. 81). Most of the printing presses were owned by Palestinian Jews by the end of $19^{\text {th }}$ century therefore they had an advantage to publish the first newspaper which covered mainly religious and few other issues. Other Hebrew religious newspapers Bitsal, $\mathrm{Ha} \mathrm{Or}$ and a magazine Yerushalaym were published during latter half of the $19^{\text {th }}$ century (pp. 84-85). The Ottomans published an official Gazette from Palestine named Al-Quds Al-Sharif both in Arabic and Turkish language (Suleiman, 2009, p. 85). From, 1905 to 1948 there were seven Palestinian Arabic-language newspapers which were published under Ottoman rule and later under British mandate. The international news organizations especially from Europe started deploying their permanent correspondents in the region after World War-I.

By 1920s, the reputed European newspapers such as Frankfurter Zeitung had deployed their permanent special correspondents in Palestine to cover the conflict (Asad, 2004, p. 137). The 
news channels like BBC and Al Jazeera and have even devised special guidelines for their correspondents working in the region to report on the conflict (BBC, 2017; Al-Jazeera, 2020). The guidelines are related to lexicons, and sensitive terms, phrases used with respect to Palestine-Israel conflict (Barkho, 2014, p. 300). The media focus on the conflict also drive the actions of the conflict parties. Durante and Zhuravskaya (2018) in their study concluded that Israeli government strategically chooses the timing of their attacks to avert negative publicity in the United States.

\section{Scholarship on traditional and social media coverage of Palestine-Israel conflict}

The communication scholars interested in the media representation of Palestine-Israel conflict have largely focused on traditional news coverage. In the last over a decade, many scholarly works about the conflict have appeared that analyzed the conflict coverage through social networking platforms such as Twitter and Facebook. The existing scholarship on traditional and social media coverage of Palestine-Israel conflict draws attention towards the absence of considerable scholarly works on social media coverage of the conflict by the traditional news organizations. Kertcher (2021) analyzed the role of Israeli sports media in promoting harmony or disintegration among Arab-Israeli population through a content analysis consisted of 300 news articles selected from three major Hebrew media sources (Kertcher, 2021, p. 4). Gonen et al. (2020) also chose three Israeli and Palestinian newspapers each to analyze evaluated the use of sources and materials originating from the opposing party (Gonen et al., 2020, p. 8). Both the studies were conducted by analyzing the traditional news organizations.

In the recent times, almost every newspaper is using social networking platforms to reach out to maximum number of people. An analysis of media effects such as of Kertcher's may not provide a holistic picture without considering the social media dimension. According to a study, Israeli users consider Facebook to be the fourth and Palestinians living in occupied territories, the seventh most important information source (Chaban et al., 2019, p. 2). Chaban et al. (2019) and Aharoni \& Tenenboim-Weinblatt (2019) also focused traditional media to lay out impact analysis. Baden and Tenenboim-Weinblatt (2018) in their study analyzed the coverage pattern of traditional media during violence and period of calm by comparing the contents of 66 domestic and foreign leading media outlets across six selected conflicts including Palestine-Israel (Baden \& Tenenboim-Weinblatt, 2018, p. 25). Another study titled 'How conflict news comes into being: reconstructing reality through telling stories' by Hoxha and Hanitzsch (2017) also focused on traditional ways of news production about PalestineIsrael and Syria conflicts (Hoxha \& Hanitzsch, 2017, pp. 49-51).

In conflict regions, the absence of on ground correspondents and cameramen renders traditional news organization completely dependent on social media activists. Therefore, any scholarly purist without considering both social and traditional media will be unable to contribute to the existing knowledge. The advent of new media is also an attractive source of information for the weaker parties of the conflict. Wolfsfeld (2018) noted that Palestinian leaders were more enthusiastic than the Israeli leaders about new communication technologies as they could use them for their advantage against a much stronger enemy (Wolfsfeld, 2018, p. 113). The study highlighted that the leaders of both sides recognized the effects of new 
communication technologies on the conflict dynamics (p. 114). A recent study conducted by John and Agbarya (2020) focused on power differential with respect to unfriending of Israeli Jews (majority group) by Palestinians (minority group) on Facebook. The study concluded that the inequality is structurally embedded in social media and the cost of cutting ties is unequally distributed among the minority and majority groups (John \& Agbarya, 2020, p. 13). The study is not directly linked to the conflict reporting but analyses the behaviour of the conflict parties on social networking website.

The 2012 Gaza war is said to be the first 'Twitter War' as the conflict parties including Hamas and Israeli forces extensively used Twitter for news feed, press releases, and media briefings (Zeitzoff, 2016, p. 6). There are exceptional studies which have focused the use of social media by traditional news organizations to cover the Palestine-Israel conflict. A study by Salminen et al. (2020) focused the level of toxicity of users' comments on social media in response to content published by the news channels. The study found out that traditional news organizations have the power to control the toxicity of the content. The study also observed that the topics such as Palestine-Israel conflict generated polarization (Salminen et al., 2020, pp.17-18). The traditional news organizations and the professional journalists have cultivated large number of followers on social media platforms due to their credibility (Manor \& Bjola, 2021, p.138).

The traditional news organizations offer one-way communication contrary to the social media that is participatory and offers multiplicity of sources and two-way communication. Zhao and Jiang (2011) observed that the traditional news organization cater limited opinions of their viewers/ readers as compared to Twitter (social media) where each Tweet has large number of comments/opinions (Zhao \& Jiang, 2011, p. 21). Teneboim (2017) opined that the traditional organizations use elite sources to authenticate the information unlike social networking platforms such as Twitter which are inclusive for being equally accessible for public, elite, and many other sources (Teneboim, 2017, p. 3501). Groves (2017) studied the 2014 Gaza war by British social media and concluded that the social networking platforms entwined the conflict with British society as compared to the traditional media (Groves, 2017, p. 332). Li and Prasad (2018) studied the use of social media by Palestinian activists where they tell their side of the stories which are often ignored by traditional news organizations (Li \& Parasad, 2018, p. 9).

Bowman and Willis (2003) argued that the hegemony of journalism has been threatened for the first time in the history because of not only the new technologies and competition but by the audience, it serves (Bowman \& Willis, 2003, p. 7). The audiences being equipped with easy-to-use web publishing tools, internet connection and increasingly powerful mobile devices, have become an active participant in the creation and dissemination of news (p. 8). Alejandro (2010) mentioned that media outlets compete to out-scoop each other but today if they hold on to a story too long, they run the risk of being out-scooped by amateurs such as bloggers, citizen journalists and Twitter users (Alejandro, 2010, p. 211). The reducing importance of legacy media and growing use of social media platforms is the focus of majority of literature (Nielsen et al., 2016, p. 7).

\section{Use of social media by traditional news organizations}

The beginning of $21^{\text {st }}$ century witnessed the expansion of worldwide internet and technological 
advancements in communication. This was the time when blogging was introduced as an alternate account to traditional media in coverage of conflicts (Bennett, 2013: p. 37). The new communication means further mediatized the conflicts. Siapera et al. (2015) divided the mediatization of conflicts in two phases. They contended that the first phase (traditional media) spanned from mid to end of $20^{\text {th }}$ century while the early $21^{\text {st }}$ century heralded the second phase (websites and social media) of mediatization of the conflicts (Siapera et al., 2015, p. 2). In the first phase, the media reporting of conflicts was one-way and centralized unlike the second phase which was more decentralized with multiple sources of information. However, Zhang (2019) quoting the study of Hoskins and O'Loughlin noted the third phase of mediatization of conflicts called 'arrested conflict' that highlights the traditional/professional media's use of social media for the conflict coverage (Zhang, 2019, p. 3). Zhang argues that social media plays enabling role in contemporary conflicts and wars while traditional news organizations and audience employ functionalities to set and counter-set the public agenda (p. 15).

Initially, all major traditional media news organizations had their websites where they posted their content. The social media websites were perceived as an opportunity by the traditional news organizations as they offered instantaneous worldwide outreach. These platforms offered interconnectedness among multiple and diverse actors including the political elite and decisionmakers (Tenenboim, 2017: p. 3500). The social media became important medium due to its socialability where a large number of people spontaneously share their emotions and opinios (Su et al., 2015, p. 1774). In case of Palestine-Israel conflict, the citizen journalism started taking its roots in 2008 (Hamdy, 2010: p. 3).

The use of social media by the traditional news organizations carries along many advantages. In the countries where press freedoms are curtailed, the social networking platforms such as Twitter are less constrained by the geopolitical boundaries (Ahmed et al., 2018, pp. 6-7). The traditional news organizations can continue to their news operations without obstruction in such states. In 2012 Gaza conflict, the conflict parties extensively used social networking platforms. The conflict is considered the first digital war between Israel and Palestinians (Kuntsman \& Stein, 2015, p. 2). The traditional news organizations such as Al Jazeera English (AJE) also used social media platforms for information gathering and news dissemination during 2012 and 2014 Gaza conflicts. Damanhoury and Rashaydeh (2017) in a comparative study of AJE and CNN's social media coverage of 2014 Gaza conflict noted that AJE used more informal sources like social media than CNN for news gathering (Damanhoury \& Rashaydeh, 2017, p. 89).

\section{Conceptus and conclusion}

The study began to highlight the existing gap in literature about social media coverage of Palestine-Israel conflict by the traditional news organizations. The review of existing literature revealed that most of the studies are focused on traditional news organizations. The conflictrelated news generate controversy and draw lot of public attention. A study by Salmenin et al. (2020) noted that the news posts about Palestine-Israel conflict generate more polarization among the social media users than any other information post. The controversy attracts public attention (Salmenin et al., 2020, p. 5). Therefore, the traditional news organizations race to out scoop the competitors to draw maximum attention of the viewers/followers/readers by posting videos/images and text about the conflict. The social networking platforms are cost-effective 
for traditional news organizations to disseminate and gather information. Being the oldest conflict in contemporary history, the political views and emotions of large number of people in relation to Palestine-Israel conflict are well defined. They not only comment, Retweet or repost but in some cases also influence the news production process by posting follow up videos/information. This is how the brand of the traditional news organizations gets promoted and they draw large number of followers and expand their communities on social networking platforms.

It was observed that the traditional news organizations have drawn huge followership on social media platforms due to growing fake news issue. Manor \& Bjola (2021) also indicated this fact in their seminal work mentioned earlier in the literature review. The netizens depend on traditional news organizations due to their professional reputation and credibility unliked social media which has fewer professional standards (Kim \& Johnson, 2009, p. 285). The traditional news outlets have fully capitalized over the opportunity offered by their professional credibility to gain popularity in the cyber space.

The study found out that the growing polarization on political conflicts such as Palestine-Israel have also exposed the divisive role of social media. Wolfsfeld's (2018) study highlighted that the Palestinian leaders were more enthusiastic about new media as it would reduce their dependency on highly centralized and easily manipulatable traditional media (Wolfsfeld, 2018, p. 111). Their enthusiasm is understandable as they are struggling against a powerful adversary which is sufficiently resourceful to manipulate the information on traditional news media. The social media is also a boon for Israel at the same time as for the Palestinians. The advantages of social media for the conflict parties also carry the potential of more divided opinions and animosity by lessening the possibility of amicable resolution of the conflict.

We observed that all such studies that employ only traditional news organizations for media coverage impact analysis are irrelevant if they do not consider along the new media. In view of digitalization of the conflicts, this study suggests that the future research on media effects should focus quantitative analysis of the social media coverage of the Palestine-Israel conflict by the traditional news organizations. The studies focused on confluence of social media and traditional media in coverage of Palestine-Israel conflict will reveal new dimensions of the media effects. These kinds of studies will also help to understand the impact of media coverage on conflict resolution and peace efforts.

\section{References}

Abufarha, N. A. (2006). The making of a human bomb: state expansion and modes of resistance in Palestine. The University of Wisconsin-Madison.

Abbasi, M. (2010). The fall of Acre in the 1948 Palestine War. Journal of Palestine Studies, 39(4), 6-27. https://doi.org/10.1525/jps.2010.XXXIX.4.6

Aharoni, T., \& Tenenboim-Weinblatt, K. (2019). Unpacking journalists'(dis) trust: Expressions of suspicion in the narratives of journalists covering the Israeli Palestinian conflict. The International Journal of Press/Politics, 24(4), 426-443. https://doi.org/10.1177\%2F1940161219841902

Alboqami, H., Al-Karaghouli, W., Baeshen, Y., Erkan, I., Evans, C., \& Ghoneim, A. (2015). Electronic word of mouth in social media: the common characteristics of retweeted and favourited marketer-generated content posted on Twitter. International Journal 
of Internet Marketing and Advertising, 9(4), 338-358. https://doi.org/10.1504/IJIMA.2015.072886

Al-Jazeera. (2020, March 28). Editorial Standards. Al-Jazeera Media Network. https://network.aljazeera.net/about-us/our-values/standards

Al-Jazeera. (2017, May 23). Don't believe these fake stories about the Manchester Arena attack [Tweet]. Twitter. Al-Jazeera English https://twitter.com/AJEnglish/status/871335745520189442

Ahmed, S., Cho, J., \& Jaidka, K. (2018). Framing social conflicts in news coverage and social media: A multi-country comparative study. International Communication Gazette, 81(4), 346-371. https://doi.org/10.1177\%2F1748048518775000

Alejandro, J. (2010). Journalism in the age of social media. Reuters Institute Fellowship Paper, 5, $1-47$. https://reutersinstitute.politics.ox.ac.uk/sites/default/files/Journalism\%20in\%20the \%20Age\%20of\%20Social\%20Media.pdf

Araujo, T., \& Neijens, P. (2012). Friend me: Which factors influence top global brands participation in social network sites. Internet Research, 22(5), 626-640. https://doi.org/10.1108/10662241211271581

Arqoub, O. A., \& Ozad, B. (2019). Israeli media gatekeeper during Gaza war 2014 coverage: Case of study of Yeditho Ahronotho newspaper. Media Watch, 10(1), 22-40. http://dx.doi.org/10.15655/mw/2019/v10i1/49560

Asad, M. (2004). The Road to Makkah. Islamic Book Service.

Baden, C., Tenenboim-Weinblatt, K. (2017). Convergent News? A Longitudinal Study of Similarity and Dissimilarity in the Domestic and Global Coverage of the IsraeliPalestinian Conflict. Journal of Communication 67(1), 1-25. https://doi.org/10.1111/jcom.12272

Baden, C., \& Tenenboim-Weinblatt, K. (2018). The search for common ground in conflict news research: Comparing the coverage of six current conflicts in domestic and international media over time. Media, War \& Conflict, 11(1), 22-45. https://doi.org/10.1177\%2F1750635217702071

BBC News. (2017, March 12). World wide web creator Tim Berners-Lee targets fake news. http://www.bbc.com/news/technology-39246810

BBC News. (2017, September 19). Israel and the Palestinians. https://www.bbc.co.uk/academy/en/articles/art20130702112133696

Barkho, L. (2014). The role of internal guidelines in shaping news narratives: ethnographic insights into the discursive rhetoric of Middle East reporting by the BBC and AlJazeera English. Critical Discourse Studies, 8(4), 297-309. https://doi.org/10.1080/17405904.2011.601642

Bennett, D. (2013). Exploring the impact of an evolving war and terror blogsphere on traditional media coverage of conflict. Media, War \& Conflict 6(1), 37-53. https://doi.org/10.1177\%2F1750635212469907

Bowman, S., \& Willis, C. (2003). We media. How audiences are shaping the future of news. A seminal report. Reston: The Media Center at the American Press Institute. https://www.yumpu.com/en/document/read/6342400/we-media-how-audiences-areshaping-the-future-of-news-and-

Boyd, D. M., \& Ellison, N. B. (2007). Social network sites: Definition, history, and scholarship. Journal of computer-mediated Communication, 13(1), 210-230. https://doi.org/10.1111/j.1083-6101.2007.00393.x 
Brennan, R., \& Croft, R. (2012). The use of social media in B2B marketing and branding: An exploratory study. Journal of Customer Behaviour, 11(2), 101-115. http://uhra.herts.ac.uk/bitstream/handle/2299/10025/jcbsubmission_280512_full_ve rsion_for_RIS.pdf\%3Fsequence\%3D1

Brewer, P. R., \& Gross, K. (2005). Values, framing and citizens' thoughts about policy issues: Effects on content and quantity. Political Psychology 26(6), 929-948. https://doi.org/10.1111/j.1467-9221.2005.00451.x

Bullard, S. B. (2015). Editors use social media mostly to post story links. Newspaper Research Journal, 36(2), 170-183. https://doi.org/10.1177\%2F0739532915587288

Carveth, R. (2004). The Economics of Online Media. In A. Alexander, J. Owers, R. Carveth, C. A. Hollifield, \& A. N. Greco (Eds.), Media economics: Theory and practice $\left(3^{\text {rd }}\right.$ ed.). Lawrence Erlbaum Associates.

Cohen, R. (2009). Israel is real. Pigador.

Cox, J. B. (2016). News orgs post more often on Twitter than on Facebook. Newspaper Research Journal, 37(3), 220-234. https://doi.org/10.1177\%2F0739532916662485

Chaban, N., Knodt, M., Liekis, Š., \& NG, I. (2019). Narrators' perspectives: Communicating the EU in Ukraine, Israel and Palestine in times of conflict. European Security, 28(3), 304-322. https://doi.org/10.1080/09662839.2019.1648256

Damanhoury, K. E., \& Rashaydeh, F. S. (2017). Is it the same fight? Comparative analysis of CNN and Al Jazeera America's online coverage of the 2014 Gaza War. Journal of Arab \& Muslim Media Research, 10(1), 84-103. https://doi.org/10.1386/jammr.10.1.85_1

Deprez, A., \& Raeymaeckers, K. (2010). Bias in the news? The representation of Palestinians and Israelis in the coverage of the first and second Intifada. International Communication Gazette, 72(1), 91-109. https://doi.org/10.1177\%2F1748048509350341

Duffy, M.J. (2011). Networked journalism and Al-Jazeera English: How the Middle East network engage the audience to help produce news. Journal of Middle East Media, $7(1)$,

$1-22$ http://www.qu.edu.qa/static_file/qu/conference/jmem2017/Vol/7/En/Networked\%2 0Journalism\%20and\%20Al-Jazeera\%20English.pdf

Durante, R., \& Zhuravskaya, E. (2018). Attack when the world is not watching? US news and the Israeli-Palestinian conflict. Journal of Political Economy, 126(3), 1085-1133. https://doi.org/10.1086/697202

Fishman, L. A. (2007). Palestine revisited: Reassessing the Jewish and Arab national movements, 1908-1914. The University of Chicago.

Ferrer-Conill, R., \& Tandoc, E. C. (2018). The audience-oriented editor: Making sense of the audience in the newsroom. Digital Journalism, 6(4), 436-453. https://doi.org/10.1080/21670811.2018.1440972

Friedman, E., \& Herfroy-Mischler, A. (2020). The media framing of blame agency in asymmetric conflict: Who is blaming whom for the 2014 Israeli-Palestinian peace negotiations failure? Journalism Studies, 21(13), 1873-1892. https://doi.org/10.1080/1461670X.2020.1797526

Groves, A. (2017). From Gaza to the streets of Britain: British social media coverage of the 2014 Israel-Gaza conflict. Jewish Culture and History, 18(3), 331-349. https://doi.org/10.1080/1462169X.2017.1364051 
Gorwa, R., \& Guilbeault, D. (2020). Unpacking the social media bot: A typology to guide research and policy. Policy \& Internet, 12(2), 225-248. https://doi.org/10.1002/poi3.184

Gonen, Y., Kampf, Z., \& Tenenboim-Weinblatt, K. (2020). Textual reservations in conflict situations: How the Israeli and Palestinian media treat each other's coverage. Journalism Practice, 1-18. https://doi.org/10.1080/17512786.2020.1796764

Hamdy, N. N. (2010). Arab media adopt citizen journalism to change the dynamics of conflict coverage. Global Media Journal: Arabian Edition, 1(1), 3-15.

Harms, G., \& Todd M. F. (2008). The Palestine-Israel conflict: A basic introduction ( $2^{\text {nd }}$ Ed.). Pluto Press.

Heo, Y. C., \& Park, H. (2014). How are newspaper companies using social media to engage and connect with their audiences? characteristics and forms of Korean newspapers' $\begin{array}{llll}\text { YouTube use. Qual } & \text { Quant, 2899-2914. }\end{array}$ https://link.springer.com/article/10.1007/s11135-013-9931-4

Hong, S. (2012). Online news on Twitter: Newspapers' social media adoption and their online readership. Information Economics and Policy, 24(1), 69-74. https://doi.org/10.1016/j.infoecopol.2012.01.004

Hoxha, A., \& Hanitzsch, T. (2018). How conflict news comes into being: Reconstructing 'reality' through telling stories. Media, war \& conflict, 11(1), 46-64. https://doi.org/10.1177\%2F1750635217727313

John, N., \& Agbarya, A. (2020). Punching up or turning away? Palestinians unfriending Jewish Israelis on Facebook. New Media \& Society, 23(5), 1-13. https://journals.sagepub.com/doi/abs/10.1177/1461444820908256

Kertcher, C. (2021). Conditioned integration during security crises: The role of Israeli sports media from 1996 to 2014. Media, Culture \& Society, 43(1), 66-83. https://doi.org/10.1177\%2F0163443720948012

Kirk, M. D. (2020). Martyrdom and the myth of motherhood: UK broadcast news media's agential construction of Palestinian female suicide bombers during the second Intifada (2000-2005). Feminist Media Studies. 1-17. https://doi.org/10.1080/14680777.2020.1808505

Kim, D., \& Johnson, T. J. (2009). A shift in media credibility: Comparing Internet and traditional news sources in South Korea. International Communication Gazette, 71(4), 283-302. https://doi.org/10.1177\%2F1748048509102182

Kramer, G. (2008). A History of Palestine: From the Ottoman Conquest to the Founding of the State of Israel. Princeton University Press.

Kuntsman, A., \& Stein, R. L. (2015). Digital militarism: Israel's occupation in the social media age. Stanford University.

Li, E. P. H., \& Prasad, A. (2018). From wall 1.0 to wall 2.0: Graffiti, social media, and ideological acts of resistance and recognition among Palestinian refugees. American Behavioral Scientist, 62(4),

493-511. https://doi.org/10.1177\%2F0002764218759582

Manor, I., \& Bjola, C. (2021). Public diplomacy in the age of 'post-reality'. In P. Surowiec \& I. Manor (Eds.), Public diplomacy and the Politics of Uncertainty (pp. 111-143). Palgrave Macmillan.

Miller, D., Costa, E., Haynes, N., McDonald, T., Nicolescu, R., Sinanan, J., . . . Wang, X. (2016). How the World Changed Social Media. University College London. 
Moscrop, J. J. (2000). Measuring Jerusalem: The Palestine exploration fund and British interests in the Holy Land. Leicester University.

McCarthy, Justin. (1990). The population of Palestine: Population history and statistics of the late Ottoman period and the mandate. Columbia University.

Nielsen, R. K., Cornia, A., \& Kalogeropoulos, A. (2016). Challenges and opportunities for news media and journalism in an increasingly digital, mobile, and social media environment. Mobile, and Social Media Environment (December 1, 2016).

Ozbay, F. A., \& Alatas, B. (2020). Fake news detection within online social media using supervised artificial intelligence algorithms. Physica A: Statistical Mechanics and its Applications, 540, 123174. https://doi.org/10.1016/j.physa.2019.123174

Pantti, M. (2013). Seeing and not seeing the Syrian crisis: New visibility and the visual framing of the Syrian conflict in seven newspapers and their online editions, JOMEC Journal, 4, 1-22. http://hdl.handle.net/10138/42895

Pennington, R. (2020). Witnessing the 2014 Gaza war in Tumblr. International Communication Gazette, 365-383. https://doi.org/10.1177\%2F1748048518825097

Said, E. W. (1979). The Question of Palestine. Vintage Books.

Shaw, S. J. (1991). The Jews of the Ottoman Empire and the Turkish Republic. MacMillan.

Salminen, J., Sengün, S., Corporan, J., Jung, S. G., \& Jansen, B. J. (2020). Topic-driven toxicity: Exploring the relationship between online toxicity and news topics. PLOS One, 15(2), e0228723. https://doi.org/10.1371/journal.pone.0228723

Segev, E., \& Blondheim, M. (2013). Online news about Israel and Palestine. Digital Journalism, 1(3). 386-398. https://doi.org/10.1080/21670811.2012.744560

Shomron, B. \& Schejter, A. (2020). Diversity in broadcasting as an enabler of capabilities: The case of Palestinian-Israeli women on public and commercial radio and television. Feminist Media Studies, 1(19). https://doi.org/10.1080/14680777.2020.1804978

Siapera, E., Hunt, G., Lynn, T. (2015). \#GazaUnderAttack: Twitter, Palestine and diffused war. Information, Communication \& Society, 18(11). 1-14. https://doi.org/10.1080/1369118X.2015.1070188

Sivarajah, U., Irani, Z., Gupta, S., \& Mahroof, K. (2019). Role of big data and social media analytics for business to business sustainability: A participatory web context. Industrial Marketing Management, $\quad 86, \quad 163-179$. https://doi.org/10.1016/j.indmarman.2019.04.005

Stassen, W. (2010). Your news in 140 characters: Exploring the role of social media in Journalism. Global Media Journal, 4(1), 116-131. https://doi.org/10.5789/4-1-15

Stieglitz, S., \& Dang-Xuan, L. (2012). Social media and political communication: A social media analytics framework. Social Network Analysis and Mining, 3(4), 1277-1291. https://link.springer.com/article/10.1007\%2Fs13278-012-0079-3

Suleiman, M. B. (2009). Early printing presses in Palestine: A historical note. Jerusalem Quarterly, 36, 79-91. https://oldwebsite.palestine-studies.org/sites/default/files/jqarticles/JQ\%2036_Early\%20Printing.pdf

Su, N., Reynolds, D., \& Sun, B. (2015). How to make your Facebook posts attractive: A case study of a leading budget hotel brand fan page. International Journal of Contemporary Hospitality Management, $27(8), \quad 1772-1790$. https://doi.org/10.1108/IJCHM-06-2014-0302

Swani, K., Brown, B. P., \& Milne, G. R. (2014). Should tweets differ for B2B and B2C? An analysis of Fortune 500 companies' Twitter communications. Industrial Marketing Management, 43(5), 873-881. https://doi.org/10.1016/j.indmarman.2014.04.012 
Talwar, S., Dhir, A., Singh, D., Virk, G.S., \& Salo, J. (2020). Sharing of fake news on social media: Application of the honeycomb framework and the third-person effect hypothesis. Journal of Retailing and Consumer Services, 57, 1-11. https://doi.org/10.1016/j.jretconser.2020.102197

Tafesse, W. (2015). Content strategies and audience response on Facebook brand pages. Marketing Intelligence \& Planning, 33(6), 927-943. https://doi.org/10.1108/MIP-07$\underline{2014-0135}$

Tenenboim, O. (2017). Reporting war in 140 characters: How journalists used Twitter during the 2014 Gaza-Israel conflict. International Journal of Communication, 11, $3497-$ 3518. https://ijoc.org/index.php/ijoc/article/view/6570/2122

Weber, M. S. (2017). The Tumultuous history of news on the web. In N. Brugger, \& R. Schroeder, Web as history, 83-100. University College London.

Wolfsfeld, G. (2018). The role of the media in violent conflicts in the digital age: Israeli and Palestinian leaders' perceptions. Media, War \& Conflict, 11(1), 107-124. https://doi.org/10.1177\%2F1750635217727312

Wolfsfeld, G. (2004). Media and the path to peace. Oxford University.

Wolfsfeld, G., Frosh, P., \& Awabdy M. T. (2008). Covering death in conflicts: Coverage of the second Intifada on Israeli and Palestinian television. Journal of Peace Research, 45(3), 401-417. https://doi.org/10.1177\%2F0022343308088818

Zeitzoff, T. (2018). Does social media influence conflict? Evidence from the 2012 Gaza conflict. Journal of Conflict Resolution, 62(1), 29-63. https://doi.org/10.1177\%2F0022002716650925

Zhao, X., Jiang, J. (2011). An empirical comparison of topics in Twitter and traditional Media. Technical Paper, Singapore Management University. file:///C:/Users/Musharaf/Downloads/Documents/TechReport(Zhao2011).pdf

Zhang, S. I. (2019). Mediatization of conflict in the social media era: A case study of SinoIndian border crisis in 2017. Journalism. Mediatization_of_conflict in the socila_media_era_(2).pdf

Zhang, X., \& Ghorbani, A. A. (2020). An overview of online fake news: Characterization, detection, and discussion. Information Processing \& Management, 57(2), 1-8. https://doi.org/10.1016/j.ipm.2019.03.004 